QUESTIONING THE 'PERFECT MALE BODY':

A CRITICAL READING OF EPHESIANS 4:13

Lilly Nortjé-Meyer

University of Johannesburg

\begin{abstract}
Many scholars are at great pains to interpret and explain the metaphor of the body in the letter to the Ephesians "correctly." From a reader-response criticism point of view, the notion of a "correct" interpretation is dubious. Metaphors point to realities beyond themselves. We use them to speak about the invisible, to understand and explain human affairs and the world of God. But metaphors are also rooted in the context of the culture and politics that created them. In this paper it is argued that the metaphor of the "perfect male body" is derived from a culture and politics that are gender biased and therefore the metaphor cannot serve as a "true," "correct" or descriptive image of the church in relationship with the transcendental.
\end{abstract}

Keywords: Perfect Male, Teleios, Polyclitus, Ephesians 4:13, Perfect Body

\title{
Introduction
}

The earliest grammatical and philosophical analyses of language indicated an interest in the functioning and meaning of metaphor that go back to the beginning of the study of language itself. Often the credit goes to Aristotle for being the first to discuss metaphor as a subject, but according to Soskice (1985, 1-3) the discussion goes even further back to the debate between nature and convention, which first arose in the fifth century B.C.E. as a principal topic amongst the pre-Socratic philosophers and later Sophists. Although Aristotle was not the first, he (and to a lesser degree Quintilian) was definitely the most important influence on all subsequent discussion of metaphor. Ironically, although the study and discussion of metaphors have such a long history, Dawes (1998, 38, footnote 64) has clearly indicated that students of metaphor can easily be overwhelmed by the terminological confusion. For example: What Macky uses the word "symbol" for, Richards calls the "vehicle" and Black the "secondary subject" of a metaphor, and this, he notes, is very close to Soskice's use of "model," and so on. Despite this confusion, Dawes (like so many others) ${ }^{1}$ has offered us a well-defined discussion of the metaphor. What makes his discussion especially important for this article is that his study is specifically based on the interpretation of the metaphor of the body in the letter to the Ephesians. I will therefore not rehearse the principles of identifying and the functioning of metaphor in general or the principles of metaphors in the text of Ephesians. It seems quite obvious from the discussions that the imagery the author uses in Eph 4:13 is indeed a metaphor, and clearly a "living" metaphor (cf. Van den Heever 1992, 93). It has a certain "semantic impertinence" which makes it impossible to take this utterance literally and it consists of signs that the language of the utterance is dependent language (cf. Dawes 1998, 77). It is also not a simile, allegory or symbol (cf. Lemmer 1998a, 95-114).

\footnotetext{
E.g., Steinhart (2001); Stern (2001).
} 
The metaphor used in Eph 4:13 is what Black $(1979,31)$ calls "the tip of a submerged model." A model is defined by Dawes $(1998,38)$ as "a consistent imaginative construct or (if one prefers) a consistent pattern of thought by means of which apparently isolated phenomena may be seen to be related to one another." The same concept is referred to by Van den Heever $(1992,94)$ as "micro and macro-metaphors." What is indeed important is to notice that the imagery used in Eph 4:13 is linked to various related metaphors in Ephesians. These form a cluster of images used in various contexts, and these contexts make up the entire whole.

It seems that the metaphor in Eph 4:13 belongs to a larger context of "body" metaphors in the text. Although the term $\sigma \omega \hat{\mu} \alpha$ (body) does not occur in Eph 4:13, the body-related terminologies used in these verses are not isolated but are strongly linked to the terms $\sigma \hat{\omega} \mu \alpha$ and $є € \phi \lambda \eta \dot{~(h e a d) ~ i n ~ E p h ~ 4: 16 . ~ T o g e t h e r ~ t h e y ~ a r e ~ a l l ~ e m b e d d e d ~ i n ~ c o n t e x t s ~ m a d e ~ u p ~ w i t h ~}$

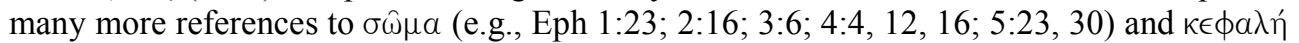

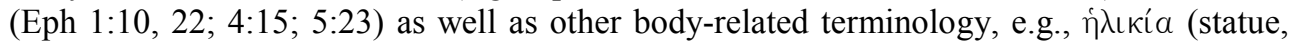

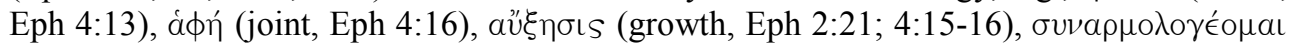
(being fitted together, Eph 2:21; 4:16), and $\sigma v \mu \beta \iota \beta a ́ \zeta \omega$ (being brought together, Eph 4:16).

What is important for our argument is the combination of $\sigma \omega \hat{\omega} \mu \alpha$ and $\kappa \epsilon \phi \alpha \lambda \eta \dot{~ t h a t ~ o f t e n ~}$ occur together in the text. ${ }^{2}$ It seems that there are three main appearances of this combination in the Ephesians text: 1:22-23; 4:4, 11-16; 5:22-33. From this combination and the appearance of other body-related terminology and metaphors, it seems that we can speak with ease about a single underlying imaginative construct, namely the model of the "body" in Ephesians.

There is also other body-related imagery that appears throughout the text, that is, $\sigma \alpha \dot{\rho} \xi$

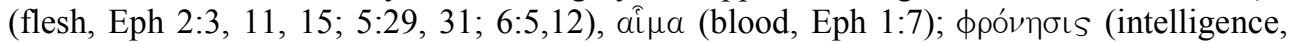

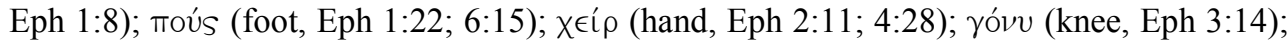

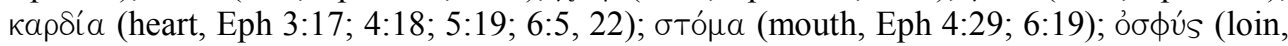
Eph 6:14). These terms are used literally and metaphorically in the text. This body-related terminology does not necessarily constitute the metaphorical model of the body that consists of the interdependent metaphors $\sigma \omega \hat{\omega} \mu \alpha$ and $\kappa \in \phi \alpha \lambda \eta$. For example, the metaphors in Eph 6:13-20 are also body language, but they constitute soldier imagery.

It is important for the argument that we first look at the use of the metaphor of the body in the wider context.

\section{The Metaphor of the Body in Ephesians}

When one examines the use of the metaphor of the body throughout the entire text, it would appear that the author used it on different levels of ideological discourse. He starts off in Eph 1:22-23 by celebrating the authority of Christ over all things: Christ has been seated in the heavenly realms far above all earthly rule and authority, power and dominion, and every title that can be given. God has put all things under his feet and appointed him as "head" (cf. Wendland 1999, 199-223). Therefore the connotation of being "head" in this context is that of totality, completeness. It seems, according to Dawes (1998, 142-143), that the author

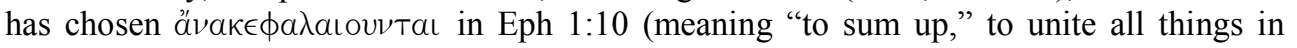

2 It seems that scholars differ as to whether $\sigma \omega \hat{\omega} \mu \alpha$ and $\kappa \in \phi a \lambda \eta ́$, when used together, are one or two metaphors. It seems that they are two separate metaphors that are used for a single underlying model. Therefore, I agree with Dawes that they are two dependent metaphors throughout their use in the letter to the Ephesians (cf. Dawes 1998, 116-119). 


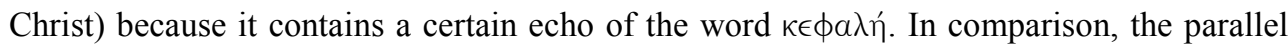
verse in Col 1:20 - the word $\alpha$ " that the expression in Eph 1:10 is similar to that which we have found in Eph 1:22 indicating the cosmic authority of Christ. When it is read in the context of the letter as a whole, Eph 1:10 implies (though it does not say) that the "unification of the universe takes place in its subordination under the Head" (Dawes 1998, 143). In conclusion, we can say

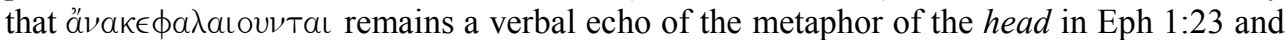
we can thus conclude that the relationship of Christ to the cosmos expressed in Eph 1:10 is

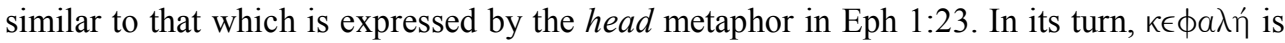
used in association with the other term to which it is closely related, namely, $\sigma \omega \hat{\omega} \mu \alpha$. The tenor of each metaphor is kept separate: Namely, the head is Christ and the body is the Church. The authority of Christ here is not an authority over the Church; it is a cosmic

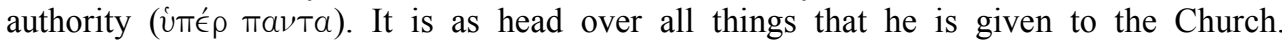
However, the cosmos is not his body, as we could have expected: In this instance the Church is his body. Dawes $(1998,141)$ explains this by saying that "the effect is that the Church has a relationship with Christ, which the cosmos does not have." In my view, this is the case because the author is interested in placing the metaphor of the body on different levels and therefore Christ as the head belongs to the macro-cosmos - namely the universe (or heavenly realms) - and the Church as the body belongs to the meso-cosmos or the society (in this case the Christian community).

The second level of hierarchical connotation of the body metaphor is to indicate the unification of the believers - first, by the unification of Jews and Gentiles and, second, by

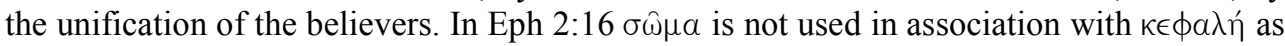
in the other contexts. It stands alone. The term "one body" is used to indicate the universal nature of the Church in the sense that it includes Jews and Gentiles, which were separated before. There are two possibilities regarding the referent of the term: The physical body of Christ as the crucified one and metaphorically the Church as his body. The "one body" stands in parallel with Eph 4:16 and therefore most scholars chose the Church as referent of the $\sigma \omega \hat{\mu} \alpha$ (cf. Hoehner 2002, 554 and O'Brian 1999, 306). Dawes $(1998,159)$ concludes that although the "one body" of Eph 2:16 refers to the Church, we cannot exclude a secondary reference to Christ himself, with reference to "his flesh" in v. $14 .^{3}$ I cannot see how the historical and therefore the physical body of Christ can come close to the Church as Christ's metaphorical body as Ridderbos $(1978,421)$ also suggested. It is with his death that he reconciles both Jews and Gentiles in "one body" and it is through his resurrection that he becomes the head (Eph 1:20).

This reconciliation or unification of Jews and Gentiles is also indicated by the adjective $\sigma u ́ \sigma \sigma \omega \mu \alpha$ (put together) in Eph 3:6, which was probably created by the author to use in parallel with $\sigma \hat{\omega} \mu \alpha$ in Eph 2:16. This term is not found in any other contemporary literature (Dawes 1998, 61). It is about the inclusion of the Gentiles as members of the body. We can assume that it has been created because of its relationship with $\sigma \omega \hat{\omega} \mu \alpha$. The same has been

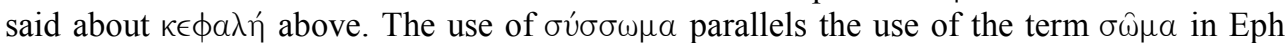
$2: 16$ because in both instances it is used to indicate the unity of Jews and Gentiles. The

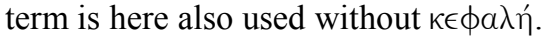

\footnotetext{
Dawes $(1998,159)$ quotes Ridderbos $(1978,421$, footnote 61$)$ to support his comments: "In these verses it comes across how close the thought of Christ's historical body and that of the Church as the body of Christ here approach each other."
} 
In Eph 4:1-6 the interaction of the two levels of hierarchical structure become more clear. Here it seems that the two worlds meet each other. In the repeated terms "one" and "everything" lay the totality of God's sovereignty over both meso- and macro-cosmos levels. The author calls upon the readers to "walk worthily of the calling in which you were called" and "to maintain the unity of the Spirit." The nature of the unity is spelled out in a series of phrases involving the term "one," which includes "one body." The Church is also the referent in Eph 4:4 as elsewhere, although the metaphor is not developed. The $\sigma \omega \mu \alpha$ is used alone without $\kappa € \phi a \lambda \eta$ or any other body references. The context refers to Christ not as head but as "Lord" (kúpıos). This confirms the interaction of the two levels of hierarchical structure: $\sum \omega \mu \alpha$ is used here to emphasize the unity of the believers.

A third level of hierarchical connotation of the metaphor of the body is introduced in Eph 5:22-33. This involves the household codes. According to Dawes (1998, 111-112) the argumentation in Eph 5:22-33 is an argument from analogy. It is been said that husbands should love their wives as Christ "nourishes and cares for his body" - the Church. It is expressed by way of the comparative particles $\omega$ s and ovitws. The wife is to the husband as Christ is to the Church. It is not said that the husband is the "Christ" or Christ is the husband of the Church. But there is a metaphorical identification at work in the verses and this takes place by way of the predication of a third term of both Christ and husband,

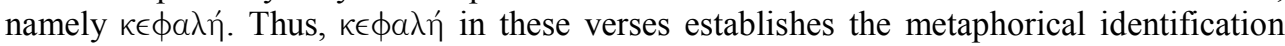
because it is the only living metaphor used in this imagery of the body in these verses. Therefore it is the "head" metaphor that links the metaphor of the body to the Church and to

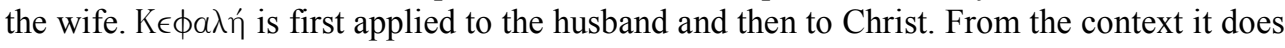
not seem as if $\kappa \in \phi \lambda \lambda \eta$ has the connotation of "source" or "creator" of the Church as indicated elsewhere (Eph 2:14-18). It seems that it is being used as a metaphor to indicate authority. The husband has the same authority over his wife as Christ has over the Church (cf. Johnson 1998, 430). Although the husband is not identified with Christ, his authority over his wife (and the household) is identified with the authority of Christ over the Church and eventually with the authority of Christ as the "head" of the universe (cf. Eph 1:10; see Nortjé-Meyer 2003, 180-193). Remarkably, the Church is never portrayed as $a$ or the head of something.

The question is now: Where does the metaphor of the "perfect man" in Eph 4:13 fit in?

\section{The Perfect Male Body in Ephesians 4:13}

It is with this background in mind that we have to explain the imagery in Eph $4: 13$. The body images in Eph 4:13-16 link with the $\sigma \omega \mu \alpha$ in Eph 4:4. Here the "one $\sigma \omega \mu \alpha$ " is mentioned together with "one spirit, Lord, faith, baptism and God." God is the only to be qualified as Father who is over all and through all and in all. The repeated use of "one" and "all" indicates a totality of the authority and sovereignty of God as Father and the totality of the peace and harmony he ensures (cf. Lemmer 1998b, 491). Within this totality functions each one, each individual. Clearly, two levels of realities meet here. This is explicitly indicated in vv. 9-10 with the ascension and descension of Christ from and into the heavenly realms. He has given to the body the gifts of authority, namely the different offices. The referent of the $\sigma \omega \mu \alpha$ in Eph 4:4 and 4:12 is clearly the Church. Although the body is mentioned without the head, the supremacy of Christ is noted in no uncertain way, namely Lord. Christ as the head of the body is again mentioned in vv. 15-16. Although Dawes $(1998,146-147)$ is of the opinion that the meaning of the head in v. 16 is that of 
"source" in correlation with Eph 5:29, I think that the authority of Christ that is strongly emphasized in the context points again to the authority of the head over the body. ${ }^{4}$ When one takes into consideration that there are a few terms indicating maturity versus immaturity (that of a child in v. 14), it is difficult to explain what kind of source the head will be for bodily growth. The same idea of totality is found in Eph 1:22-23: God "appointed him to be head over everything for the Church, which is his body, the fullness $(\pi \lambda \eta \dot{\rho} \omega \mu \alpha)$ of him who fills everything in every way."

The "oneness" of the body is compared with a man's physical body. Amazingly, for the understanding of this body it is worth noting that in Eph 2:15 the author has used for the same idea the word $\alpha^{\prime \prime} \nu \rho \omega \omega \pi$ os and not $\alpha \nu \eta ́{ }^{5}$ So it seems that the use of the image of a man is quite significant. Freely translated it is more in the following sense: Everybody should come unto a perfect man, unto the dimensions of the full stature of Christ. The tenor in this case is not the church, but Christ, actually the full statue of Christ. The author used various bodily terms to describe the body and its function from growth to maturity in detail in vv.

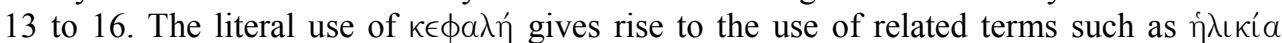

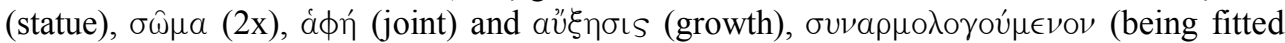
together), and $\sigma v \mu \beta \iota \beta a \zeta{ }^{\prime} \mu \in v o v$ (being brought together). The body is a male body still maturing, but not a child anymore, well structured and fitted (in other words, in proportion), each joint is working according to its function (no dysfunction of any body part). Therefore,

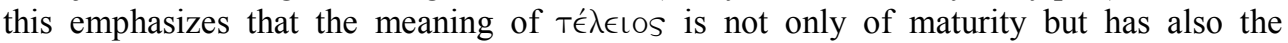

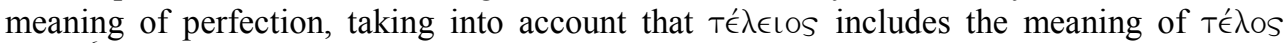
(end). ${ }^{6}$ Ancient artists' creation of this amazing body led to the general public demand of the regulatory body and specified it as a perfect, balanced and non-excessive body. In Eph

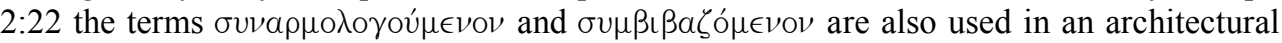
context, and this gives the connotation of something carefully planned and constructed.

What does "in everything unto the stature of the fullness of Christ" mean? It cannot be the physical body of Christ. He does not have a physical body anymore. In this context it means to come to the full authority, power and love of Christ as head of the Church and as Son of God. It is the only reference in the text of Ephesians to Christ as Son of God. Like the Greco-Roman society, the Church used Christ as the regulatory body to inscribe its hierarchies. He stands at the highest point of the hierarchy of bodies. The perfect man is like Christ. The ultimate body of Christ is used to demarcate, circulate and differentiate the bodies the Church controls.

The body is not only a flesh and blood entity, but is actually created by the society it lives in. In antiquity the male body was the norm. Everything that did not match a particular male body was defective and dysfunctional. Therefore, the female body was a defective body merely because it was not a male body. Moreover, the body of a man from the aristocracy was considered to be of better quality than that of a man from the populace.

\footnotetext{
It is also important to note that the word $\tau$ té $\lambda \in \operatorname{los}$ is used.

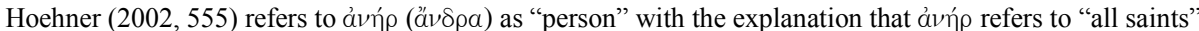
and that includes everybody. But the problem is that "all saints" only refers to male officials (cf. Thurston 1998, 138).

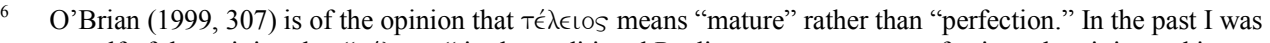
myself of the opinion that "TÉ $\lambda \in L_{O S}$ " in the traditional Pauline corpus means perfection when it is used in connection with God and Christ and maturity when it is used in connection with human beings (cf. Nortjé

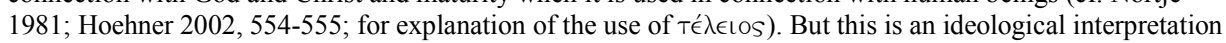
which holds that only God, and not a human being, can be perfect. Therefore, I am of the opinion that $T \epsilon ́ \lambda \in \operatorname{LS}$ means "perfect," irrespective of whether it is used in connection with God or a human being.
} 
In the rest of the letter to the Ephesians the author emphasizes the harmony and unity (cf. Syreeni 2002) of the Christian community (namely the body of Christ). The community is still not perfect like the "regulatory body" but this is the encouragement: To become more and more like the perfect body. The perfect man matches the body stature of the head of the community. He is the epitome of masculinity. This is the image the author wants to give to the Christian community among its pagan neighbours.

We can compare the image of the perfect man with the image of the perfect balanced body that Greek artists composed.

\section{The Perfect Male Body in Antiquity}

Greek art was never just a simple mirror of everyday Greek life. These images are fantasies, metaphorical constructions intended to express a particular politics of truth about the human condition. "The art bodies forth a Greek politics of truth in the same way as the gender constructions of the text" (Stewart 1997, 12).

Therefore, the human body embodied the ideologies of its society. The male body embodied power and strength and the female body embodied vulnerability and weakness. The ideal and superior body was a male body and this resulted in the occurrence of a "onesex" model (cf. Laquer 1990). The ideal male body was perfectly proportioned according to a formula that related all its parts mathematically to one another. The first to reflect this ideology in antiquity was the professional commentary on sculpture, namely the Canon of Polyclitus, probably written during the third quarter of the fifth century B.C.E. The Canon was the most renowned ancient commentary on art. We do not have the original document, but enough information is preserved in existing ancient texts to enable us to form some conception of its content. The aim of the Canon was not simply to explain a statue but also to achieve to кa入óv, "the beautiful" and to $\in \hat{U}$ (the perfect or the good) in it. The secret of

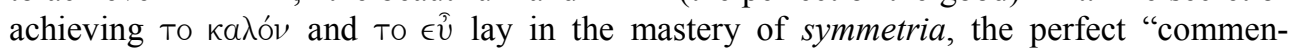
surability" of all parts of the body to one another and to the whole.

Galen, a physician from the second century, based his comments on the idea of health in the body on the treatise of Polyclitus (the document is now lost) on the body: "Beauty resides not only in the commensurability (symmetria) of the constituents (that is, of the body), but in the commensurability of parts, such as the finger to the finger, and of all the fingers to the metacarpus and the wrist (carpus), and of these to the forearm, and of the forearm to the arm, in fact of everything to everything, as it is written in the Canon of Polyclitus." Polyclitus not only described all the symmetriae of the body in his treatise, but also demonstrated his ideas in a work, a statue of a man according to the tenets of his treatise, and called the statue itself, like the treatise, the Canon (cf. Pollitt 1972, 106).

Another aspect that is important for a discussion of the metaphor of the body and specifically of the "perfect male body" is Polyclitus' idea of symmetria and the pursuit of the то ка入óv and то $\in \hat{v}$, which was probably influenced by exposure to the ideas of Pythagoras (sixth century B.C.E.) and of his followers. Pythagoreans were concerned with finding some underlying pattern in visual phenomena. Their fascination with numbers was directly related to the belief that they could find the key to physical bodies in numbers, and that numbers also held the key to abstract qualities like justice. As a demonstration of this principle, they explored musical harmony and noted how the intervals needed to produce harmonic chords on the string of a lyre were expressible in a limited group of integers $(2: 1$;

Cf. Porter (2002). 
3:2; 4:3, etc.). This led Pythagoras to search for these patterns in other visual phenomena like the movements of the planets and the relationships of the stars. He believed that these underlying harmonic proportions could be found throughout nature. These patterns demonstrated the Greek conception of nature as cosmos (cf. Pollitt 1972, 107).

Ephesus was known in antiquity for its sacred shrines. Excavations on the site have uncovered statues by Polyclitus. Taking the above explanation and analysis of "the perfect male body" in Eph 4:13 as well as the image of the perfect male body of the statue of Polyclitus into account, it seems that the ideology of Polyclitus and the patriarchal ideology of ancient society influenced the way the author of Ephesians constructed the body metaphor. Stewart $(1997,88)$ reminds us that the image of the perfect male was prized not only for the esthetic value it had, but that Polyclitus' spear-bearer was in the first place a soldier. This tilted the scale in favour of the image of the perfect male as being perfect and not just mature, because the last pericope of Ephesians ended with the parenesis of a soldier wearing the armour of God. Furthermore, it seems that the author of Ephesians developed the underlying model of the body on three levels to fit into the hierarchical division of his ideological thought about God, the Church and the household.

\section{Conclusion}

It is obvious that the early Church maintained the Roman public politics to produce a certain kind of body, the regulatory body, to demarcate, circulate and differentiate the (Church) bodies it controlled (cf. also Martin 1995, 36-37). The active male body energized by its excessive heat is therefore suited in nature to office-bearing, decision making, managing and labour outside the domain of the household, while natural legitimacy is given to the woman's place in the household. No wonder that in the letter to the Ephesians women are given no place or official offices in the Church. For this they are too impure and out-of-place.

Therefore, the patriarchal connotation of the image of the perfect male is problematic. The question is: How perfect can a man be? In ancient time women were honoured because they embodied life-giving characteristics. They were able to give life and maintain life through their bodies and lose a considerable amount of blood (as the essence of life) each month without dying (cf. Ferguson 1995, 5). Therefore, they were considered to have control over life and death. So, in a patriarchal society the male body might be idealized as being perfect but, from a human point of view, the perfect male body lacks the ability to give life and maintain life - the most important factor on earth and indispensable for the continuation of the culturally ascribed bodies. Without life, the body, ascribed or real, is dead.

Therefore, to use the male body as an image to explain the meta-reality of God is misleading and a false image of the transcendental. I would not argue for replacing the male body with the female body as the perfect body, but without the female body the perfect male body is perfectly dead.

P.S.: This ideology is still alive in our society today. Amazingly, during a visit to Germany in August 2004 I came across a family magazine which covered the 2004 Olympic Games in Athens. The topic of one of the main articles was "Der perfekte Sportler" with a photo image of the German discus thrower Lars Riedel (37). It seems that the image was carefully composed because the athlete imitates a statue: He posed naked in action with his body painted in bronze color with seven arrows indicating the most important body parts that make him a perfect sportsman. At the end the author makes the 
following comment: "Wichtig ist die Koordination aller Bewegungen, die im Kopf perfect durch-gespielt wird" (Von Frenckell 2004, 4-5). This echoes the ideas of Polyclitus and Pythagoras that the underlying harmonic proportions are carefully composed to form a perfect man.

\section{BIBLIOGRAPHY}

Black, M 1979. More about Metaphor. Pages 19-43 in Metaphor and Thought. Edited by A Ortony. Cambridge: Cambridge University Press.

Dawes, GW 1998. The Body in Question. Metaphor and Meaning in the Interpretation of Ephesians 5:21-33. Leiden: Brill.

Ferguson, M 1995. Women and Religion. Englewood Cliffs: Prentice Hall.

Hoehner, HW 2002. Ephesians. An Exegetical Commentary. Michigan: Baker Academia.

Johnson, EE 1998. Ephesians. Pages 428-432 in Women's Bible Commentary. Expanded Edition with Apocrypha. Edited by CA Newsom and SH Ringe. Louisville: Westminster John Knox Press.

Laquer, T 1990. Making Sex: Body and Gender from the Greeks to Freud. Cambridge: Harvard University Press.

Lemmer, HR 1998a. Movement from Allegory to Metaphor or from Metaphor to Alegory? “Discovering” Religious Truth. Neotestamentica 32(1):95-114.

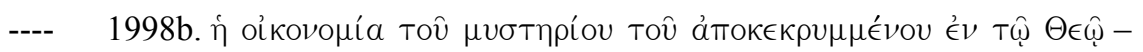
Understanding "body of Christ" in the Letter to the Ephesians. Neotestamentica 32(2):459-496.

Martin, DB 1995. The Corinthian Body. New Haven: Yale University Press.

Nortjé, SJ 1981. Die Begrip Teleios by Paulus. MA. Thesis, Rand Afrikaans University.

Nortjé-Meyer, SJ 2003. Die Hiërargiese Funksionering van God, Mans en Vroue in die Brief aan die Efesiërs. Verbum et Ecclesia 24(1):180-193.

O’Brian, PT 1999. The Letter to the Ephesians. Grand Rapids: William B Eerdmans Publishing Company.

Pollitt, JJ 1972. Art and Experience in Classical Greece. Cambridge: London: Cambridge University Press.

Porter, JI (ed.) 2002. Constructions of the Classical Body. Michigan: University of Michigan Press.

Ridderbos, HN 1978. Paulus. Kampen: Kok.

Soskice, JM 1985. Metaphor and Religious Language. Oxford: Clarendon Press.

Steinhart, E 2001. The Logic of Metaphor: Analogous Parts of Possible Worlds. Dordrecht: Kluwer Academic.

Stern, JJ 2001. Metaphor in Context. Cambridge: MIT Press.

Stewart, A 1997. Art and Desire and the Body in Ancient Greece. Cambridge: Cambridge University Press.

Syreeni, K 2002. Paul and Love Patriarchalism: Problems and Prospects. A paper presented at the Potchefstroom workshop. Potchefstroom, September 16-17. 
Thurston, B 1998. Women in the New Testament. Questions and Commentary. Companions to the New Testament. New York: Crossroad.

Van den Heever, GA 1992. Theological Metaphors and the Metaphors of John's Gospel. Neotestamentica 26(1):89-100.

Von Frenckell, J 2004. Wunder Athlet. Funk Uhr. Das Fernseh-Magazin. 34 (August):2127.

Wendland, ER 1999. Contextualising the Potentates, Principalities and Powers in the Epistle to the Ephesians. Neotestamentica 33(1):199-223. 